\title{
6 Between closing borders to refugees and welcoming Ukrainian workers
}

\author{
Polish migration law at the crossroads
}

\author{
Witold Klaus
}

\section{Introduction $^{1}$}

Article 2 of the Treaty on European Union serves as a cornerstone of the values of European Union (EU) and its Member States. The Union itself is built on values that include: respect for human dignity; freedom; democracy; equality; the rule of law; and respect for human rights, including minority rights. According to the Treaty, several values are common to the society of the EU. These are: pluralism, non-discrimination, tolerance, justice, solidarity, and equality between women and men. All of these are moral principles and a beacon for each and every legislation accepted both on the EU and Member State levels. One of the important aspects of the process of Europeanization is spreading these values throughout the Member States and the neighboring countries (particularly those applying for EU membership) inter alia by including them into their legislation (Mtchedlishvili 2018).

The processes described above are rather general, and apply to a number of policies, such as foreign policy or European integration policy. But when it comes to Europeanization of migration policy that has been growing since the 1990s, another phenomenon can be observed.

[T]he Europeanization of migration policy fosters the securitization of migration it sustains a radical political strategy aimed at excluding particular categories of people by reifying them as a danger (for example, to cultural values, to the provision of social assistance, to public safety, to health etc.)

(Huysmans 2000: 771)

In the last few years however, another process has been taking place in Central-Eastern Europe that Peter Vermeersch identifies as 'the process of de-Europeanization.' Politicians who have been implementing de-Europeanization also appeal to values - values that were supposedly 'forgotten' by the EU. These politicians are trying to re-establish and defend what they call 'Christian values' (Vermeersch 2019). De-Europeanization is theoretically built on patriotism, reflecting the diverse nationalistic attitudes of its 
founding fathers in each nation. Poland serves as one example where the deEuropeanization of EU policies is occurring.

But do European migration policies reflect European values described in Art. 2 of the Treaty on European Union? In my opinion, those values are very difficult to find there. Instead, current EU migration policy puts the idea of security first and foremost as a 'super right' (or we might say as a 'super value') that justifies practically all decisions (Lemke 2014: 69-70) and brings us to the point where any other value should be subjugated to it. As a result, we are starting to face discrimination against non-EU nationals, lack of tolerance and solidarity, lack of the principle of the rule of law, etc. Thus, current EU migration policy contradicts a number of values that the EU legislation should obey. Those values are being further twisted and abused in countries where the de-Europeanization process, with its nationally-focused approach based on the exclusion of others, is taking place.

In this chapter, I deconstruct the values that Polish migration policy is built on by analyzing legal and bureaucratic activities undertaken by the Polish authorities after 2015. I present, as well, the ambiguity of this policy that vacillates between strengthening security by closing borders to refugees on the one hand, and accepting a large number of Ukrainian labor migrants on the other. I start with a short overview of the inflow of migrants and asylum seekers to Poland over the past 15 years. Then I briefly present Polish migration policy and its development after 2004 with special focus on the changes introduced after 2015, which were justified by a dramatic change of attitudes in Polish society towards refugees. Against this backdrop, I describe the most recent and very divided approach of the Polish government to asylum seekers and economic migrants, which is reflected in legal acts or proposed legislation. Drawing from these trends, I reconstruct the values that serve as the foundation for these changes.

\section{The inflow of foreigners to Poland}

Immigration has a very short history in Poland. Since the nineteenth century, Poland has mainly been a country of emigrants. For many years, the primary reasons for Poles leaving were economic and political. Following the collapse of communism in 1989, emigration remained high and increased even further after 2004 when Poland joined the EU. In 2011, the Polish Central Statistical Office estimated that over two million Poles remained outside Polish territory for a minimum of three months and 1.6 million stayed abroad for at least a year (Fihel \& Kaczmarczyk 2009; Goździak 2014; Kaczmarczyk \& Okólski 2002, 2008; Stola 1992).

For many years Poland remained a country without immigrants. In communist times, the border was practically closed and immigration scarce, with some small exceptions for students from other socialist African and Asian countries. Immigration picked up after 1990, but even then it was mainly circular and short-term by individuals undertaking irregular employment or 
involved in other forms of 'shadow economy.' The majority of immigrants to Poland were citizens of neighboring countries, primarily Ukrainians (Brunarska et al. 2016; Górny 2017; Kaczmarczyk \& Okólski 2002), people with cultural and linguistic backgrounds similar to Poles.

Between 1990 and 2012, the overall number of migrants living in Poland slowly increased, ranging between 50,000 and 150,000 . But this is not the case for Ukrainians. Before 2015, Ukrainians comprised about 30 percent of all foreigners holding residence permits, but since then their number has increased due to emigration after Russia's aggression on Ukraine in 2014. In 2018, almost two-thirds of all non-EU nationals holding temporary or permanent residence permits were Ukrainian citizens. Many more Ukrainians were working in Poland under a visa regime - with different estimates identifying as many as 1.5 million Ukrainians in Poland in 2018 (Górny et al. 2018).

Legal immigration from Ukraine was possible because of exceptionally liberal Polish labor migration legislation. A system of declarations entrusting work to foreigners has been in operation since $2007 .^{2}$ It was an easy way to obtain the necessary documents and then a visa granting legal entry and employment in Poland for six months over a 12-month period, therefore many people used this opportunity to leave Ukraine. ${ }^{3}$ Many Ukrainians had previously tried and tested the system, which made it more familiar to subsequent immigrants, and laid a ground for well-established Ukrainian social networks (Szulecka 2016b). In 2015, there was a huge increase in the number of declarations of entrusting work to a foreigner - 17 times more declarations were issued compared to the previous year, a figure which doubled again in 2016. Ukrainians constituted 98 percent of individuals who obtained the document in 2015. Ukrainians still accounted for 91.5 percent of foreigners who obtained the declarations in 2018 (Górny et al. 2018). A similar trend is also apparent if we look at work permits, although in this case the representation of Ukrainians stands at 75 percent to 85 percent in recent years, and the number of permits issued is distinctly lower.

It therefore seems that a significant group of Ukrainians used well-known channels of economic migration resulting in an unprecedented influx of Ukrainians to Poland. Despite armed conflict in Ukraine, most Ukrainians opted out of applying for international protection in Poland or any other EU country, although many Ukrainians have sought protection in Russia (Szczepanik \& Tylec, 2016).

\section{Refugees and asylum seekers in Poland}

The Polish asylum system has only been developing for fewer than thirty years, since it was only in December 1991 that Poland signed the 1951 Convention Relating to the Status of Refugees. While Poland welcomed refugees in the communist era from Greece (1948-56) and Chile (1973), the total number amounted to a mere 20,000 individuals. Since 1992, there was a consistent, albeit insignificant, inflow of asylum seekers reaching almost 


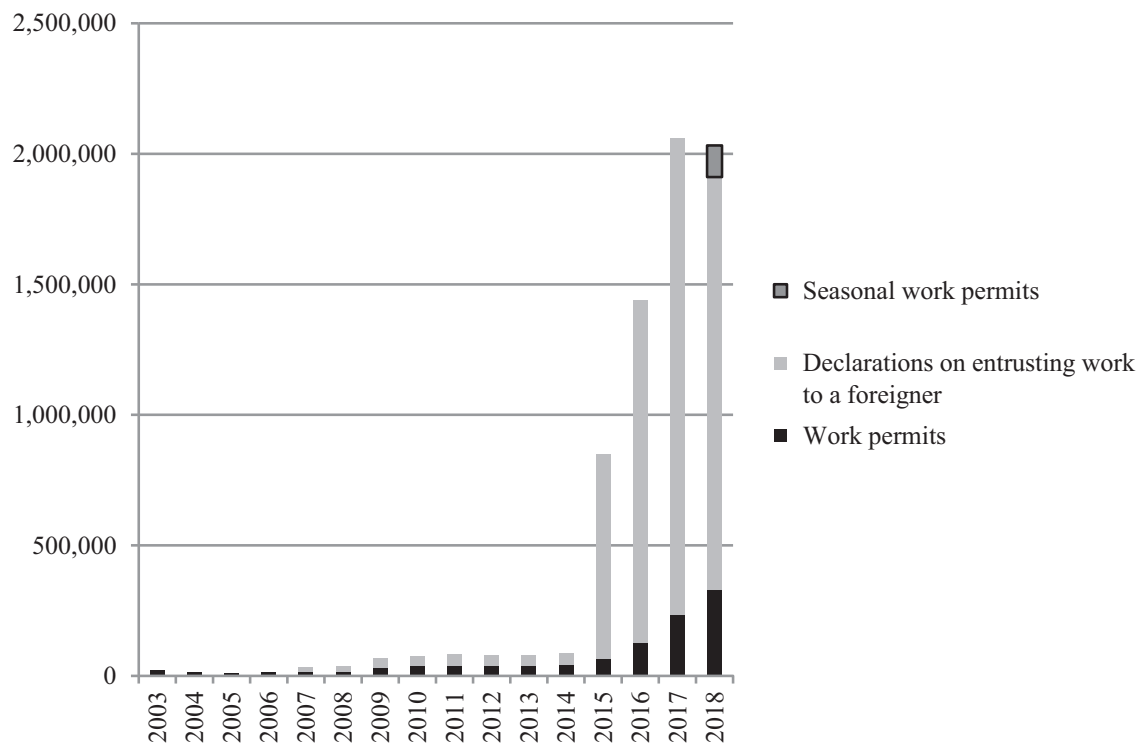

Figure 6.1 Number of work permits and declarations on entrusting work to a foreigner, issued between 2003 and $2018^{4}$

Based on: MoF 2019a; MoF 2019b

15,000 applicants in 2013. However, most of them did not stay in Poland and ended up going to other Western European countries. Few received any form of international protection. In the 1990s, only 100 individuals received protection annually, around 2,500 people annually between 2005 and 2009, and since 2010 only a few hundred people per year (see Figure 6.2). Generally speaking, the Polish asylum system is not very friendly towards asylum seekers. The chances of obtaining any form of protection are low, e.g. between 2011 and 2016 only 2 percent of applicants received refugee status, the lowest recognition rate in the entire EU. Meanwhile, refusal to be granted international protection comes with serious consequences - the foreigner must leave Poland and is often barred from entering the EU for several years.

The history of asylum in Poland can be divided into two periods. During the 1990s, individuals seeking protection came mainly from Sri Lanka, Pakistan, India, and Bosnia and Herzegovina. Since 2000, the biggest number of asylum seekers have been Russian citizens of Chechen nationality, of which over 100,000 came to Poland. Tellingly and oddly, the Polish asylum system has not registered a big number of Syrians. They began arriving in Poland after 2011 and by the end of 2018 represented only 889 individuals. However, most of the Syrians who stayed in Poland received refugee status. This cannot be said of the Chechens, for whom obtaining refugee status is nearly impossible. Instead, the Chechens might receive other forms of international protection such as subsidiary protection or humanitarian stay. 


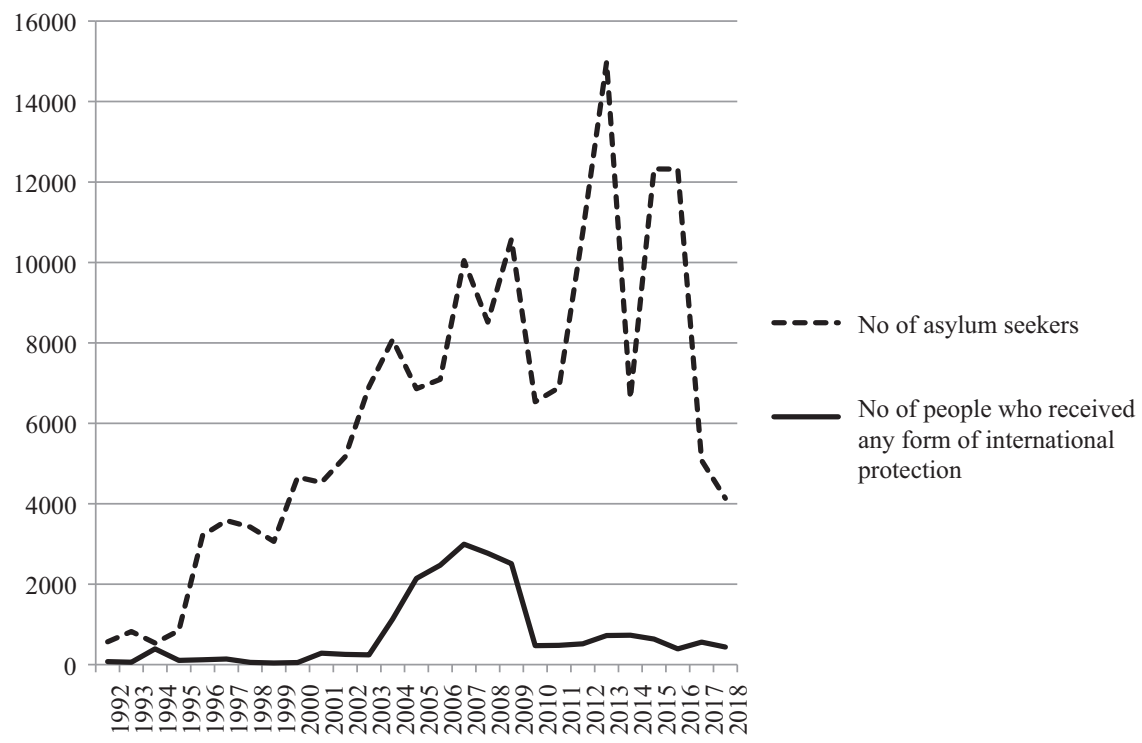

Figure 6.2 Number of foreigners, who apply for international protection and who Based on: OF 2019 were granted any form of international protection in Poland 1992-2018

In recent years, however, even these forms have been granted to Chechens exceptionally rarely. For instance, in 2018, only nine people were granted refugee status in Poland and 70 individuals obtained subsidiary protection.

Very few Ukrainians decided to apply for international protection in Poland, mostly residents of the Crimea and the Donbas region (Düvell \& Lapshyna 2015; Szczepanik \& Tylec 2016). In the five years from 2014 to 2018, Ukrainians submitted 7,066 asylum applications, with 65 percent submitted in 2014 and 2015, and less than 7 percent in 2018. Only 743 Ukrainians were granted some form of international protection, mainly subsidiary protection. The relatively low number of Ukrainian asylum seekers in Poland is a consequence of an assumption demonstrated by many EU states that Ukrainians should seek support in their home country since they are entitled to internally displaced persons' status based on the 'internal flight alternative.' Over 1.6 million Ukrainians have internally displaced persons' status, but their situation is so dire that they have no alternative but to emigrate (Krakhmalova 2018).

\section{Short overview of Polish migration policy and its history}

To enable its accession to the EU, Poland incorporated the entire body of the EU acquis common rights and obligations into its national legal order. Poland also changed its migration law based on EU regulations, which 
significantly influenced Polish legal institutions (Łodziński \& Szonert 2017). It adopted the European perspective on migration, which in the mid-1990s began to place more and more emphasis on security, curbing migration (especially the number of asylum seekers), and the protection of borders. The solutions instituted in the Polish migration law were primarily about implementing the EU regulations without regard for Polish migration reality or needs, even contradicting them at times (e.g. the obligation to introduce visas for Ukrainian nationals). These solutions were devised to address the expectations and needs of the 15 old member-states of the EU (Vermeersch 2005; Huysmans 2000).

Formal work outlining assumptions of Polish migration policy began in 2007 and ended in 2012, with the government adopting a document entitled 'Polish Migration Policy - Status Quo and Plan of Action.' The work was conducted mainly by representatives of ministries and nongovernmental organizations as well as other experts, but without the participation of politicians who, at that time, did not exhibit any interest in migration issues. The resulting policy was described as 'apolitical' (Łodziński \& Szonert 2017), meaning that Polish migration policy was developed from scratch, without a political vision, to address a low immigrant influx to Poland, and a significant acquiescence to the regulations and schemes developed on the EU level. Some of these EU schemes aided the thinking on migration in Poland (especially as regards integration of migrants), but Europeanization also came with its own baggage of negative implications resulting from perceiving migration through the issues of security and associated restrictive legislation (Pawlak 2013).

All of those processes - security-based foundation of immigration law, lack of rootedness of issues related to migration in programs of political parties, weakness of migration policy and its instruments - laid the foundations for what happened in Poland in 2015 and was an indirect consequence of the so-called refugee crisis. The consequences are indirect, since practically no refugees from the Middle East ever reached Poland, but the 'threat' of them entering the country became a key element of the parliamentary election in 2015 and was addressed by all political parties. The newly-elected government continued anti-immigration rhetoric, which had proved so successful during the campaign by bringing them victory, and initiated several changes in the law. In October 2016, the government also cancelled the 'Polish Migration Policy - Status Quo and Plan of Action' (Klaus et al. 2018: 482-7; Krzyżanowska \& Krzyżanowski 2018). A new version has never been prepared.

Jacek Skiba, Deputy Minister of Internal Affairs, responsible for migration issues in 2015, outlined the migration policy of the government in the following words: 'We are moving away from the ideological approach. In our opinion the ideological approach, based on the vision of multicultural and broad migration absorption, is flawed.' For the government 'the safety factor is extremely important, which is particularly clear in view of the recent 
terrorist attacks,' and 'the source of migration in the case of Poland should not be the Middle East area. The natural area is east of our borders' (Biuletyn Migracyjny 2016).

The change of public discourse had a dramatic impact on the public opinion towards refugees - the number of people opposing the acceptance of refugees rose from 21 percent in May 2015 to 61 percent in April 2016 (Klaus et al. 2018). The shift in public attitudes fueled the government's actions - politicians presented themselves as enforcers of the will of the people. The government's initiatives, accompanied by speeches of its representatives and their subordinated public media, played a powerful role in shaping public opinion. In the June 2017 poll, 19 percent of Poles associated the word 'refugees' with terrorists, another 14 percent linked them with 'Islamists,' and 15 percent thought it was synonymous with economic migrants. In general, half of the respondents expressed a negative attitude towards refugees, while positive sentiments were reported by only 15 percent of the polled group (Defratyka 2017). The public debate around the influx of refugees in the wake of the so-called refugee crisis contributed to a growing fear of terrorism among Poles. While in 2010 one in three polled respondents recognized the presence of a genuine terrorist threat in Poland, in 2016 this number had doubled (Feliksiak 2016).

\section{Attitudes towards refugees and asylum seekers after 2015 and its reflection in law and public policies}

After 2015, the Polish government undertook a range of legislative initiatives with the aim of portraying refugees (or, more broadly, foreigners) in a negative light - as dangerous individuals and a menace to society. One of them was the introduction of the Act of 10.06.2016 on Antiterrorist Activities. This Act authorizes law enforcement to use a wide range of powers to carry out surveillance of individuals in the territory of Poland. The new regulations define 'terrorist activities' very broadly in order to justify intervention of law enforcement, but they also fail to provide for sufficient supervision by independent courts. According to the 2015 law, all foreigners (e.g. all individuals without a Polish citizenship, including nationals of other EU Member States), are perceived as particularly suspicious. The regulations authorize almost unrestricted surveillance of this group, including phone tapping, audio and video bugging the house, and access to all forms of correspondence and data aggregated or sorted electronically by the person. A new procedure for temporary arrest was also introduced solely based on the probability that a particular person committed, attempted to commit, or prepared to commit a crime of a terrorist nature. Court proceedings can be conducted based on materials that neither the arrested individual nor their defense lawyer will have access to, rendering effective defense virtually impossible (Klaus 2017). These practices mirror those described by Andrew Cole as based on the assumption that the human rights of 'enemy aliens' 
might be sacrificed in the name of the right of citizens to security in the "war on terrorism' (Cole 2003).

A closer inspection of the 2015 Act reveals that particular powers are focused on providing protection against 'Islamic radicals.' The catalogue of terrorist events included in the version of the bill submitted to the parliament by the Polish government (Sejm ${ }^{5}$ paper no 516 of 2016) contained numerous references to Islam and its links with terrorism and extremism, including conferences and seminars organized by foreigners from so-called high-risk countries, and prison visits by imams, despite the fact that under Polish law each prisoner has the right to meet ministers of their own faith. The catalogue featured all offences committed by inhabitants of centers for asylum seekers. During parliamentary work the above list was reviewed and the current regulation ${ }^{6}$ makes no reference to religion, which had been replaced by the neutral term 'international extremism.' The catalogue of terrorist events was modified to remove the absurd examples mentioned above. However, certain groups are still seen as particularly dangerous due to their religion or ethnicity, such as when the mere presence of a foreigner is deemed as a terrorist incident simply because of the individual's ethnicity or religion. Disclosure of an offence committed by a resident of a center for asylum seekers is often treated as a potential terrorist incident.

Objections by some right-wing political parties to relocation and resettlement schemes were one of the important elements of the 2015 parliamentary election campaign. Such objections were also high on the agenda of the Law and Justice Party. They continued after the party came to power in the form of vocal protests against relocation and resettlement both in Poland and on the EU level (Wiacek 2017). At the same time, legislative action in the Polish Parliament continued to prepare for the eventuality of relocations. In the autumn of 2015, the Parliament introduced measures to raise awareness of security issues by requiring a determination by the Chief of Police, Internal Security Agency, and Border Guard whether a particular asylum seeker posed a threat to the defense and security of the state if they would have been relocated to Poland. Notwithstanding, the new government decided to further toughen the rules in 2016. The time dedicated to screening the asylum seeker requesting relocation or resettlement was extended from seven to 45 days and officials were now required to submit the security report on every foreigner. Previously, the absence of a report within the statutory period was interpreted as the absence of a threat on the part of the person. If any law enforcement agency identifies a threat, the government must refuse relocation or resettlement. Furthermore, the decision to deny relocation or resettlement is not accompanied by any justification, cannot be appealed, and is communicated to all other member states.

The government has also been working on a more general modification of the Act on Granting Protection to Foreigners since 2016. ${ }^{7}$ Every few months, a new amended version of the provisions emerges. The latest, third version of the draft was announced on February 4, 2019. The objective of 


\section{W. Klaus}

the legislation remains the same: to obstruct asylum seekers' access to international protection in Poland. The rationale for the third draft is that most of applicants are not 'genuine refugees.' In fact, the explanatory memorandum to the draft explicitly 'contains solutions to prevent the abuse of the institution of international protection by foreigners who, for reasons other than protection from persecution ... apply for said protection ... [and wish to circumvent the conditions] for crossing the external border of the European Union.' Using the 'logic' of the Polish government, special legal measures should be introduced to prevent 'abuse of refugee procedures by economic migrants.' These new mechanisms are intended not only to efficiently manage asylum processes, but also 'contribute to internal security of the state and protect the public order' (MoI 2019: 1-2).

All versions of the draft amendments provide for the introduction of accelerated border procedures with the aim of promptly handling unsubstantiated cases. Nevertheless, the list of situations allowing authorization of the border procedure is very long and covers a multitude of potential cases, including situations when the asylum seeker offers incoherent or contradictory explanations to corroborate persecution in the country of origin. It should be taken into account that the procedure of submission of an asylum application is prompt and it takes place under conditions not conducive to confidentiality, hence the potentially cryptic explanations. Other situations covered in the draft include instances when, in the opinion of a border guard, the asylum seeker poses a threat to the security of the state, or when the asylum seeker has destroyed their identification document. ${ }^{8}$ These broad formulations raise concerns that the vast majority of applicants will be fast tracked to border procedures whose primary raison d'être is speed and efficiency - the procedure should be finalized within 20 days which leaves very little time to investigate the case thoroughly. Another problem is that the procedures in the draft amendments come with considerable limitations to legal safeguards of the person and involve obligatory detention of the foreigner and their family in a detention center. What's more, an asylum seeker has no right to challenge decisions applying the border procedure to him or her. Furthermore, a negative decision denying international protection issued during the procedure is final. No administrative court proceedings can stop the expulsion of the foreigner from the territory of Poland.

In 2019, the third version of the draft also reduced the scope of protection offered to asylum seekers who have experienced any form of violence, abuse, or torture. At the moment, at least in theory, such survivors cannot be detained in a guarded center. The amendment will narrow applicability to survivors of torture and inhuman treatment, so that, for instance, women who survive abuse, including sexual abuse, will be susceptible to detention.

With plans to detain increasing numbers of asylum seekers, in November 2017, the government changed the legislation so that it now enables placing foreigners in barracks/shipping containers during their detention. Whole detention centers for foreigners may consist of containers only, behind a 
minimum three-meter fence fortified with barbed wire. The mental image is bound to conjure up a familiar and uncomfortable associations with fascist and communist camps during and after World War II.

These legal changes which have been introduced or are planned by the government reflect a radical shift in interpretation of existing asylum laws resulting in Polish borders being sealed. The number of asylum seekers that were allowed to apply for asylum dropped notably between 2017 and 2018 . This drop was not related to a change in the situation in the asylum seekers' countries of origin (primarily Chechnya), but rather was a result of marked shift in attitudes of Polish authorities towards asylum seekers and the effective closure of the Polish border to refugees. The process began in the summer of 2015 and has been gaining strength ever since. In 2018, on average, one family per day was allowed to enter Poland to apply for asylum, while the remaining people were turned away (mostly to Belarus ${ }^{9}$ ). The Polish Border Guards turn a deaf ear to requests for asylum. Desperate asylum seekers, at the moment mainly from Chechnya (in the years 2015-2016 also from Tajikistan), are relentless in their attempts to submit an application in Poland, trying several dozen times, with a record of 60 attempts. Some succeed, many don't. The whole process is humiliating and financially draining as asylum seekers need to pay for accommodation in Belarus and train tickets to Poland. Additionally, asylum seekers staying in Belarus risk being sent back to Russia by Belarusian authorities and being delivered into the hands of Chechen authorities, as they can only legally stay in Belarus for three months (Klaus 2017; Szczepanik 2018).

The situation, at odds with the Polish and international law, is the result of political decisions and a manifestation of the government's reluctance to accept refugees, Muslims in particular. And it's not a coincidence that both Chechens and Tajiks, targeted mostly by this policy, are followers of Islam. In similar fashion, the systematic refusal to grant Chechens international protection is a manifestation of the same trend. The Polish government maintains that Chechnya is a peaceful, war-free region, therefore there is no excuse for its nationals not to go back. If, however, for some unlikely reason they cannot stay in Chechnya, other regions of Russia are available. This is an example of ideological blindness that contravenes international organizations' reports on the situation in the region.

\section{Law and its responses to economic migration to Poland 2015-2018}

Despite the fact that the process of securitization of migrants was taking place, at the same time Poland has become a leader among EU countries in accepting new migrants. Over the years, employers have grown used to the presence of Ukrainians in the Polish job market. Low unemployment, which has decreased steadily since 2013 and was below 6 percent in June 2018 (GUS, 2019), along with an economic boom and significant emigration of Poles to other EU states has resulted in shortages in the labor market. 
Recruitment of Poles was often impossible due to lack of interest in the advertised low-skilled vacancies and the gap has been filled by labor migrants, predominantly Ukrainians (Wysieńska-Di Carlo \& Klaus 2018). Employers realize that they simply cannot manage without foreigners, but at the same time their attitudes towards migrants are not very open. In their eyes, Ukrainians are nothing more than cheap labor addressing pressing temporary shortages who will miraculously disappear when the demand expires. Moreover, business owners seem to assume that the workforce supply will continue as long as there is demand, but there is little evidence of any long-term expectation of migration. When employers think of foreigners, they mean Ukrainians, and they are rather reluctant to hire people of other ethnicities (Kubiciel-Lodzińska \& Maj 2017; Wysieńska-Di Carlo \& Klaus 2018).

Since 2015, there has hardly been a united governmental front as far as economic migration is concerned. In terms of legislation, there has been friction and differences of opinion between the Ministry for Internal Affairs and ministries responsible for economy and the labor market. Representatives of the Ministry of Interior advocated restrictions for economic migrants by tightening the legalization of their stay and work procedures. At the same time authorities responsible for economic growth favored a more relaxed approach, promoting the interests of Polish economy, and easing pressure from business owners (Gońda \& Klaus 2018).

The bone of contention was the approach to declarations on entrusting work to foreigners. The regulation had long been criticized as leaving room for abuse - it allowed big groups of foreigners (as discussed above) to arrive legally, but left the authorities with little control over the process, neither did they sufficiently safeguard migrants arriving to work. As a consequence, the regulations enabled people to arrive legally, but a lot of them took up illegal forms of employment ${ }^{10}$ (Szulecka 2016a). It allowed employers to reduce labor costs (by not paying taxes and social security contributions, disregarding health and safety measures, etc.), but the flip side was that it often led to cases of abuse of Ukrainian workers by Polish employers (Keryk 2018).

Preparation to change the regulation with regard to declarations began in connection with Poland having to implement Directive 2014/36/EU on the conditions of entry and stay of third-country nationals for the purpose of employment as seasonal workers (which partially overlapped with declarations' system). As a result, the legislation concerning declarations was slightly modified in 2018 by granting more control over the process to various public services. Moreover, there was some consideration over how to incorporate the new seasonal work permits into the system existing in Poland. The ministry of internal affairs insisted they be controlled by the government, which would render the legislation practically defunct making it too bureaucratic and difficult to manage. Eventually, the permits are issued by local authorities, which are also responsible for registering declarations in 
the central electronic system. The procedure itself is not overly complicated and it resembles declarations. In fact, both institutions complement each other - any work deemed seasonal requires seasonal work permits, while the remaining ones are based on declarations of entrusting work to a foreigner. In addition, as a result of pressure exerted by employers and their organizations, many Polish regions did away with labor market tests for certain occupations in the process of issuing work permits. The role of the test was to verify whether the vacancy might be filled by a Pole. Since the shortage of candidates in some low-skilled jobs has been very acute, the test is disregarded in construction, for truck drivers, domestic workers, and kitchen workers. Owing to this change, employing a foreigner became a less timeconsuming affair (Wysieńska-Di Carlo \& Klaus 2018).

The ministries of economy and labor engaged in further planning of how to facilitate foreigners' access to the labor market in Poland. In the summer of 2018, they put forward a draft labor market bill which would extend the working period from six to 12 months based on declarations on entrusting work to a foreigner. In the process of social consultation, employers' organizations and NGOs jointly demanded further and more progressive changes provide more flexibility in employing migrants (SIP 2018). However, work on the bill was suspended by the government without any notice or explanation, and the document itself vanished from the governmental website. It shows ambiguity within the Polish government when it comes to migration law and, more general, migration policy.

\section{Values and Polish migration policy after 2015}

Legal provisions should reflect values of the society, so it is worth taking a look at attitudes of Polish society towards migrants. Data from the European Social Survey ${ }^{11}$ shows that while Poles do not perceive migrants as a serious threat, but they also don't like them and don't want them on Polish soil (Wysieńska-Di Carlo 2018b). The high level of antipathy towards foreigners is a result of xenophobic sentiments, particularly towards Muslims, Roma or Jews, instead of general anti-immigrant attitudes (Wysieńska-Di Carlo 2018a). Catholicism has a lot to answer for in this state of affairs - it plays an important role in establishing Polish identity and is instrumental in reinforcing the concept of Poland as a 'bulwark of Christendom.' Thus, there is a strong link between the dislike of foreigners and islamophobia, as well as a conflation of refugees with Islamic terrorists (Goździak \& Márton 2018). Still, Polish xenophobia is hardly a new phenomenon. It's long been a fixture in the Polish cultural landscape, temporarily obscured from sight by the more recent need to be perceived as part of the European community (Vermeersch 2019).

Despite the fact that opinion polls show Poles accepting of foreigners, as long as they are ethnically similar (Wysieńska-Di Carlo 2018a), it would be disingenuous to claim that Ukrainians are made to feel overly welcome by 
Polish society - only one in four Poles admits to liking Ukrainians. Indeed, in the last two years Poles have become more insular and their friendliness towards people from all nations has waned, particularly for individuals from Asian, Arab, and Roma ethic groups (Omyła-Rudzka 2018).

Xenophobia, which we could call an 'anti-value,' has been very present in Polish migration policy since the end of 2015. It laid a good foundation for number of legislative initiatives, bureaucratic attitudes, or lack of changes that I described above. It is easy to see from the $s$ and arguments of the Polish government that the paramount value that guided authorities to introduce various initiatives has been based on fear and security derived from xenophobia. Ensuring security requires the identification of the enemy that commands fear. Currently, refugees - dehumanized, depicted as terrorists, and posing an ultimate threat on the physical and cultural level - constitute that enemy. Once the 'good enemy,' as Jock Young put it, is defined, and the danger made real, we have the right and obligation to resort to any measure to defend ourselves (Young 2007: 35f). Society presents government with a carte blanche to act on its behalf, and security becomes a new super value overriding others, including human dignity, freedom, equality, the rule of law, and respect for human rights.

Peter Vermeersch observes that EU values also include reconciliation and common prosperity. Recently, EU values have been perhaps upstaged by petty national claims borne out of historical insecurities and the childish blame game of who is innocent and who is guilty. The trend is notably visible in the countries of Central and Eastern Europe, including Poland, where a new value of victimhood has been born. Victimhood nationalism feeds off moral superiority, hurt, and a sense of threat from the enemy outside. Victimhood nationalism is based on the assumption that although we are now plenty, we used to be the oppressed minority whose rights were violated. If we fail to act, history might repeat itself.

In the Polish case, contemporary victimhood politics includes such topics as the potential victimisation of Poles through ethnic heterogeneity and multiculturalism; the threat posed by Marxist multiculturalism and the EU for Catholic and Polish speaking identity, and the potential loss of sovereignty.

(Vermeersch 2019: 120)

Thus, acting on behalf of society to protect it becomes a moral obligation. The external enemy is forever shapeshifting, assuming the form of the EU, whose values the Polish government rejects, or various minorities like refugees and migrants. Confronted with such threats, the Polish government is obliged to defend the Polish nation from enemies - even though they are imagined and falsely created than real. Indubitably, this is exactly how the Law and Justice government understands its mission. 
In a number of situations, the Polish government has acted in line with European migration legislation. However, these similarities do not mean that Polish values are in line with European values. One could assume that European law mirrors European values, but when it comes to migration law it seems that this is not the case. Stripping asylum seekers of basic rights like fair trial and personal freedom, closing borders in refugees' faces, letting people drown in the sea and punishing civil society activists for rescuing them, sending refugees back to other countries where they are not safe - all of these behaviors are allowed by the EU legislation. They are far away from any values that should be common to all Europeans.

\section{Notes}

1 Research presented in this article is part of the project 'Ensuring the safety and public order as a justification of criminalization of migration' financed by the National Science Center, Poland under the grant number 2017/25/B/HS5/02961.

2 While the work permit system in Poland is very similar to the most of systems operating in other EU countries, Polish specificity is an invention of a parallel and simplified system called 'a system of declarations of entrusting work to a foreigner.' It allows employers to register a foreign employer in a very fast and easy procedure, without many formalities, and free of charge (since the beginning of 2018 a symbolic fare have been introduced). The system was primarily invented for seasonal workers, but after a few months it was broaden and started to cover all forms of labor. Planned as an exception and supplement to the main system of work permits, the system of declarations of entrusting work to a foreigner has become a leading procedure for employment of foreigners in Poland (see: Szulecka 2016b).

3 Apart from Ukrainians, the scheme is also available to Armenians, Belarusians, Russians, Georgians, and Moldovans.

4 The data shows the number of documents issued, rather than the number of people. It is especially important in the context of declarations entrusting work to a foreigner, since a number of declarations can be issued for one person. Also, not every person who obtained the declaration arrived in Poland. It is estimated that around 60 to 65 percent of the total number of declarations issues translates into the number of individuals who came to Poland and work there (Górny et al. 2018).

5 Sejm is the name of the lower chamber of the Polish parliament.

6 Decree of the Minister of Interior and Administration on the catalogue of terrorist events.

7 The subsequent stages of the work are documented at https://legislacja.rcl.gov. $\mathrm{pl} /$ projekt $/ 12294700 / \mathrm{katalog} / 12410554$.

8 Unfortunately, the measures are generally in line with the provisions of Directive 2013/32/EU on common procedures for granting and withdrawing international protection (recast).

9 Over 90 percent of asylum applications have been in fact submitted over the years in one and the same Border Guard facility - at the train border crossing between Poland and Belarus, in the small town of Terespol.

10 There is wide social acceptance for unregulated work both in Poland and in Ukraine.

11 More information about this research could be found here: www.europeansocia lsurvey.org/ 


\section{References}

Biuletyn Migracyjny (2016). "Pragmatycznie, a nie ideologicznie” - o polityce migracyjnej Polski Jakub Skiba, Sekretarz Stanu w MSWiA, w rozmowie z Renatą Stefańską i Moniką Szulecką,' Biuletyn Migracyjny 55, pp. 2-4.

Brunarska, Z., Kindler, M., Szulecka, M., \& Toruńczyk-Ruiz, S. (2016). 'Ukrainian Migration to Poland: A “Local” Mobility?' in Fedyuk, O. \& Kindler, M. (eds), Ukrainian Migration to the European Union. Lessons from Migration Studies. Cham: Springer, pp. 115-132.

Cole, D. (2003). Enemy Aliens: Double Standards and Constitutional Freedoms in the War on Terrorism. New York: The New Press.

Defratyka, A. (2017). 19\% Polaków kojarzy słowo „uchodźcy’ z terrorystami (sondaż). Available at: http://ciekaweliczby.p1/19-polakow-kojarzy-slowo-uchodzcy-z-terror ystamiakow-kojarzy-slowo-uchodzcy-z-terrorystami/

Düvell, F. \& Lapshyna, I. (2015). 'The EuroMaidan protests, corruption, and war in Ukraine: Migration trends and ambitions,' Migration Information Source, Online Journal of the Migration Policy Institute. Available at: www.migrationpolicy.org/article/ euromaidan-protests-corruption-and-war-ukraine-migration-trends-and-ambitions

Feliksiak, M. (2016). Zagrożenie terroryzmem. Komunikat z badan 127. Centrum Badania Opinii Społecznej. Available at: www.cbos.pl/SPISKOM.POL/2016/K_127_16.PDF

Fihel, A. \& Kaczmarczyk, P. (2009). 'Migration: A threat or a chance? Recent migration of Poles and its impact on the Polish labour market,' in Burrell, K. (ed.) Polish Migration to the UKin the 'New' European Union After 2004. Farnham and Burlington: Ashgate, pp. 23-48.

Gońda, M. \& Klaus, W. (2018). 'Czynniki kształtujące polskie polityki imigracyjną i integracyjną w opinii badaczy i praktyków,' Polityka Społeczna 45(11/12), pp. 16-23.

Górny, A. (2017). 'All circular but different: Variation in patterns of Ukraine-toPoland migration,' Population, Space and Place 23(8). Available at: https://doi.org/ $10.1002 /$ psp. 2074

Górny, A. et al. (2018). Imigranci w Polsce w kontekśsie uproszczonej procedury zatrudniania cudzoziemców. Warszawa: Ośrodek Badań nad Migracjami UW. Available at: www.migracje.uw.edu.pl/wp-content/uploads/2016/11/raport-power.pdf

Goździak, E. M. (2014). 'Polish migration after the fall of the Iron Curtain,' International Migration 52(1), pp. 1-3.

Goździak, E. M. \& Márton, P. (2018). 'Where the wild things are: Fear of Islam and the anti-refugee rhetoric in Hungary and in Poland,' Central and Eastern European Migration Review 7(2), pp. 125-151.

GUS (2019). Unemployment Rate 1990-2018. Warszawa: Central Statistical Office. Available at: https://stat.gov.pl/en/topics/labour-market/registered-unemployment/ unemployment-rate-1990-2018,3,1.html

Huysmans, J. (2000). 'The European Union securitization of migration,' Journal of Common Market Studies 38(5), pp. 751-777.

Kaczmarczyk, P., \& Okólski, M. (2002). 'From Net Emigration to Net Immigration Socio-economic Aspects of International Population Movements in Poland,' in Rotte, R. \& Stein, P. (eds) Migration Policy and the Economy: International Experiences. Munich: Hanns-Seidel-Stiftung, Academy for Politics and Current Affairs, pp. 319-348.

Kaczmarczyk, P., \& Okólski, M. (2008). 'Demographic and labour-market impacts of migration on Poland,' Oxford Review of Economic Policy 24(3), pp. 599-624. 
Keryk, M. (2018). Working in Poland: Violations of the Labour Rights of Ukrainian Migrants in the Construction and Services Sectors. Warszawa: Fundation "Our Choice". Available at: http://pl.naszwybir.pl/wp-content/uploads/sites/2/2018/03/raport-online-en.pdf

Klaus, W. (2017). 'Closing gates to refugees: The causes and effects of the 2015 "Migration Crisis" on border management in Hungary and Poland,' Yearbook of the Institute of East-Central Europe 15(3), pp. 11-34.

Klaus, W., Lévay, M., Rzeplińska, I. \& Scheinost, M. (2018). 'Refugees and asylum seekers in Central-European Countries - reality, politics and the creation of fear in societies,' in Kury, H. \& Redo, S. (eds) Refugees and Migrants in Law and Policy Challenges and Opportunities for Global Civic Education. Cham: Springer, pp. 457-494.

Krakhmalova, K. (2018). 'Internally displaced persons in pursuit for access to justice: Ukraine,' International Migration. Available at: https://doi.org/10.1111/imig.12500

Krzyżanowska, N. \& Krzyżanowski, M. (2018). "Crisis” and migration in Poland: Discursive shifts, anti-pluralism and the politicisation of exclusion,' Sociology 52(3), pp. 612-618.

Kubiciel-Lodzińska, S. \& Maj, J. (2017). 'The tendency of entrepreneurs to employ foreigners: Labour immigrants in the opinion of employers,' Central and Eastern European Migration Review, 6(2), pp. 176-191.

Lemke, T. (2014). 'The risks of security: Liberalism, biopolitics, and fear,' in Lemm, V. \& Vatter, M. (eds) The Government of Life: Foucault, Biopolitics, and Neoliberalism. New York: Fordham University Press, pp. 59-74.

Łodziński, S. \& Szonert, M. (2017). “Niepolityczna polityka”? Kształtowanie się polityki migracyjnej w Polsce w latach 1989-2016,' Studia Migracyjne - Przeglad Polonijny, 2(164), pp. 39-66.

MoF (2019a). Foreigners Working in Poland 2008-2018. Statistical Data by the Ministry of Family, Labor and Social Policy. Available at: https://archiwum.mpips.gov.pl/ana lizy-i-raporty/cudzoziemcy-pracujacy-w-polsce-statystyki/

MoF (2019b). Seasonal Work Permits 2018. Statistical Data by the Ministry of Family, Labor and Social Policy. Available at: http://psz.praca.gov.pl/web/urzad-pracy/ -/8180228-zezwolenia-na-prace-sezonowa-cudzoziemca

MoI (2019). Uzasadnienie do projektu ustawy o zmianie ustawy o udzielaniu cudzoziemcom ochrony na terytorium Rzeczypospolitej Polskiej oraz niektórych innych ustaw. 6 May. Available at: https://legislacja.rcl.gov.pl/docs//2/12294700/12410552/12410553/dokum ent379937.docx

Mtchedlishvili, D. (2018). 'Theorising Europeanisation in European literature: Conceptualisation and operationalisation,' Australian and New Zealand Journal of European Studies 10(1), pp. 79-91.

OF (2019). Statistical Data on Proceedings Regarding Foreigners in Poland 1998-2018 by the Office for Foreigners. Available at: https://udsc.gov.pl/statystyki/raporty-okre sowe/zestawienia-roczne/

Omyła-Rudzka, M. (2018). Stosunek do innych narodów. Komunikat z badan 37. Warszawa: Centrum Badania Opinii Społecznej. Available at: www.cbos.pl/SPISKOM. POL/2018/K_037_18.PDF

Pawlak, M. (2013). 'Imitacja w tworzeniu polskiej polityki integracji cudzoziemców,' Studia Migracyjne - Przeglad Polonijny 39(3), pp. 97-122.

SIP (2018). Remarks of Employers' Organizations and NGOs to the Project of the Act on Labor Market of 2018 Regarding Employment of Foreigners in Poland. Available at: https://interwencjaprawna.pl/wp-content/uploads/2018/08/pismo-do-m inisterstwa.pdf 
Stola, D. (1992). 'Forced migrations in Central European history,' The International Migration Review 26(2), pp. 324-341.

Szczepanik, M. (2018). 'Border politics and practices of resistance on the eastern side of "Fortress Europe": The case of Chechen asylum seekers at the BelarusianPolish border,' Central and Eastern European Migration Review 7(2), pp. 69-89.

Szczepanik, M., \& Tylec, E. (2016). 'Ukrainian asylum seekers and a Polish immigration paradox,' Forced Migration Review 51, pp. 71-73.

Szulecka, M. (2016a). 'Paradoxes of formal social control. Criminological aspects of foreigners' access to the polish territory and the labour market,' Biuletyn Polskiego Towarzystwa Kryminologicznego 23, pp. 79-95.

Szulecka, M. (2016b). 'Regulating movement of the very mobile: Selected legal and policy aspects of Ukrainian migration to EU countries,' in Fedyuk, O. \& Kindler, M. (eds) Ukrainian Migration to the European Union. Lessons from Migration Studies. Cham: Springer, pp. 51-72.

Vermeersch, P. (2005). 'EU enlargement and immigration policy in Poland and Slovakia,' Communist and Post-Communist Studies 38, pp. 71-88.

Vermeersch, P. (2019). 'Victimhood as victory: The role of memory politics in the process of de-Europeanisation in East-Central Europe,' Global Discourse: An Interdisciplinary Journal of Current Affairs 9(1), pp. 113-130.

Wiącek, E. (2017). 'Poland's refugee policy and polish society between values of survival and self-expression,' Relacje Międzykulturowe - Intercultural Relations 2. Available at: www.ism.uj.edu.pl/wp-content/uploads/2017/11/IR-Cultures-Values-Identities-2017-nr. 2.pdf\#page $=166$

Wysieńska-Di Carlo, K. (2018a). 'Niechęć wobec migrantów: rasizm i ksenofobia w Polsce na tle europejskim,' in Sztabiński, P. B. \& Sztabiński, F. (eds) PolskaEuropa. Wyniki Europejskiego Sondażu Społecznego 2002-2016/17. Warszawa: Wydawnictwo IFiS PAN, pp. 25-34.

Wysieńska-Di Carlo, K. (2018b). 'Zmiany w opiniach wobec imigracji w Polsce na tle europejskim,' in Sztabiński, P. B. \& Sztabiński, F. (eds) Polska-Europa. Wyniki Europejskiego Sondażu Społecznego 2002-2016/17. Warszawa: Wydawnictwo IFiS PAN, pp. 10-24.

Wysieńska-Di Carlo, K. \& Klaus, W. (2018). Pracodawcy i pracodawczynie a zatrudnianie cudzoziemców i cudzoziemek. Warszawa: Stowarzyszenie Interwencji Prawnej. Available at: https://interwencjaprawna.pl/dla-pracodawcow/files/SIP_RAPORT_ FULL_ONLINE_pdf

Young, J. (2007). The Vertigo of Late Modernity. Los Angeles and London: SAGE Publications. 